\title{
The Inscribed And Outspread Verses of Allah Both Point Toward The Relationship of Man And Nature
}

\author{
Muhammad Yusuf ${ }^{1}$, Mardan Mardan' ${ }^{2}$ Achmad Abu Bakar ${ }^{3}$ \\ \{muh.yusuf1274@gmail.com ${ }^{1}$,mardan@uin-alauddin.ac.id²,achmadabubakar@uin-alauddin.ac.id ${ }^{3}$ \} \\ ${ }^{1}$ Sekolah Tinggi Agama Islam Al-Furqan Makassar, Indonesia \\ ${ }^{2}$ Universitas Islam Negeri Alauddin Makassar, Indonesia \\ ${ }^{3}$ Pascasarjana Universitas Islam Negeri Alauddin Makassar, Indonesia
}

\begin{abstract}
The inscribed and outspread verses of Allah both point towards the relationship of man and nature. Man is brought about to serve as emissary of mercy to the worlds. This article expresses the relationship between man and nature in adherence to qawliyah-quraniyah and kawniyahverses. The study of qawliyah-quraniyah verses reveals harmony between their messages and natural phenomena. With a thematic exegetical method, agreement between both is found in depicting the relationship of man to nature, which is not between subject and object but of a mutualistic symbiosis. Partial comprehension of holy texts has produced partial understanding as well, partly stemming from the factor of past tahlili and ijmali methodologies of commentary that concentrate on text but do not offer thorough explanations on any issue. Consequently, it is not uncommon that nature finds itself at the receiving end of man's tyrannical behavior. A thematic text-reading method with an interdisciplinary approach is thus considered an apt choice to provide a comprehensive account of man and nature's relationship.
\end{abstract}

Keywords: Relationship, Verse, Methodology, Interdisciplinary, Mutualistic Symbiosis

\section{Introduction}

Nature often falls victim to man's cruelty, and in turn reacts to man's actions against it. Essentially, man and nature are companions that ought to greet, look after, give to and benefit from each other. The vast expanse of earth underpinning towering mountains akin to sturdy walls barring hurricanes and storms, mounts that look green, tender and heartwarming, and vast blue oceans stretching out, stowing priceless gold and pearls, are all created by Allah for the pleasure of His intelligent creatures [1]. As national treasure, the extensive lush tropical rainforests of Indonesia are the last home and haven of unique biological wealth of the world. The biodiversity of Indonesian forests covers $12 \%$ mammal species, $7.3 \%$ species of reptiles and amphibians, and $17 \%$ species of birds worldwide, while there remain many unidentified and mysterious species within. World Wildlife Fund (WWF) data indicate that in 1994-2007 alone over 400 new species were found in the jungle of Kalimantan Island [2]. Regrettably, in the midst of such abundant wealth, there are always those among men who impair their connection with their natural environment. 
The greatest damages or threats against natural forests are illegal logging, shifting cultivation, forest fire, and unsustainable exploitation for residential and industrial development or due to encroachment. Exacerbating forest damage upsets the balance of the forest ecosystem and its surrounding environment, leading to disharmony or disequilibrium [3] such as in the case of human-wildlife conflict over living space [4]. The Quran as inscribed verses and guide for every nation of mankind is perpetually studied as pilot information for research despite the disbelief of some people [5].

Environment is the nature surrounding the living space of man and all living creatures, whereas environmental pollution is the defilement and blemish of such natural surroundings. The air and the seas have been suffering from pollution, the ozone layer has continued to shrink and animal species have died out. Added to this situation is pollution of the social environment, namely penury, dispossession, vagrancy, migrant issues, racism, child abandonment, substance abuse, alcoholism, etc. Numerous contemporary scholars and experts have underlined the central role of religion in tackling these problems and in building comprehensive and integral environmental awareness [6].

The first AREVA FCVS (FCVS Standard) was developed by AREVA almost 30 years ago in response to the Chernobyl accident [7]. The first three, also called incidents, only have an effect inside a plant, while the four levels of accidents (levels 4-7) involve various levels of radioactive releases to the environment. Three Mile Island, for instance, is ranked level 5 on this scale whereas the severe accidents of Chernobyl and Fukushima are ranked level 7. While the US approach focuses on core cooling and preventing core melt $(2,4,5)$ the IAEA approach generally postulates the release of contaminants $(6,8,9)[8]$. As supercritical fluid operations generally end in venting part of the gaseous fluid, possibly added with a co-solvent, impact of SCF emission in atmosphere must be evaluated on several aspects: Toxicity, flammability, atmosphere pollution related to VOC release (especially tropospheric ozone photosynthesis), long-term effects (green-house effect, stratosphere ozone depletion). Disposal of SCFs that are liquid at room conditions (water, some hydrocarbons and alcohols) will not be considered in this paper as it is generally managed classically

\section{Research Method}

Comparing a number of theories on man and nature's relationship, this study begins by reciting the holy texts of the Quran which discuss about man and nature both explicitly and implicitly. The examination of Quran verses is conducted by means of al-Mu'jam al-Mufahras li Alfazh al-Qur'an [9], whilst the exegesis uses a thematic content analysis approach. The Qurani conception of relationship between man and natutre is studied through implicit tracking by linguistic [10], interrelationship [11],[12], and contextual approaches [13], the latter of which incorporates the historical and reality context of the verses' revelation.

\section{Theory Analysis}

Prior to exploration of key concepts in the Quran on the relationship of man and his natural surroundings, this paper discusses several perspectives or attitudes attributed to religion, or rather a deviant or partial grasp of it, that become the root of recent problems. They determine how man 
interacts with and positions himself in his environment, and mainly pertain to the various connections between man and the universe

First, anthropocentric view. An anthropocentric point of view is thought as the prime factor that shapes the exploitative trait of man toward nature. Such outlook to some extent stems from monotheistic believers' understanding of their Scripture, particularly concerning the creation of the universe and its purpose. Anthropocentrism derived from monotheistic religious texts believes that the earth and sky are created to serve the interest of man [14]. In fact, White (1974) [15] explicitly accuses Christianity as the most anthropocentric religion in its view that man has divine transcendence; that man is created through God's image and thus embodies His dominion on Earth. Hence, exploiting nature for the welfare of man is seen as no other than God's will.

Second, dualistic view. The worldview emerging from religious comprehension strongly influences how man perceives his position toward nature and God. As White (1974) [16] explains, Judeo-Christian theology detaches man from the universe in that man considers himself its ruler or conqueror. Moreover, the dualistic notion that the universe and man therein are separate from God as Creator arises out of monotheistic traditions. According to many experts, such dualism causes man to see the profane world arbitrarily exploitable solely in the name of development and prosperity without weighing in the impact on the worldwide environment.

Thirth, the intrinsic value of nature. The idea of whether nature's intrinsic value exists also links to the narrative of creation in the holy texts of monotheistic religions. A global modern perception partly taken from reading Holy Scriptures is that creatures other than man do not possess any intrinsic value; that nature is comparable to trifling machinery with no sense of purpose. Another basis for this view is John Locke's theory of primary and secondary qualities, in which nature merely bears primary qualities without any secondary qualities because nature is thought to have no soul and intelligence at all. Secondary values arise through the intervention of man. For instance, a tree or wood only gains worth when made into chairs, tables or other tools by man. As expressed by Özdemir [17], such insight utterly abolishes the inherent quality of nature. Creatures beside man simply offer an instrumental value to man as they are created to cater for his benefit as man maintains the highest order on Earth [18],[19]. This mindset may bring about disrespectful behavior toward nature and entice humans to assume the right to manipulate the natural environment to their hearts' content.

Fourth, escapist eschatological orientation. Eschatologically oriented religious beliefs and teachings, observed from a general viewpoint, inform the attitude and behavior of adherents who disregard the environment [20]. The eschatological angle in question, among others, sees life in this world akin to a place to stop by and gather provisions for the afterlife. Real life is not in this world but in the Hereafter. Another eschatological proclivity is John Haught's "apocalyptic religiosity" which regards the universe as finite and bound to destruction, so that if such is its destiny, man needs not bother saving Earth from blight. Thereby, it can be inferred that this perspective has no concern over the environment [21]. Haught dubs such orientation as "cosmic (terrestrial) homelessness" where man is just an alien in the world. On one side, this creed is potentially hazardous to nature, but on the other side, it could extend to a positive direction in terms of the cosmological theory of the Big Bang. This theory stresses that the universe including man is on a very lengthy and perennial cosmic voyage, an insight that can be applied alongside the ideal of "homelessness" as religious anxiety ("religious homelessness"). Haught $(2004,2006)$ [22] 
retains that "religious homelessness" is not "cosmic homelessness," i.e. man is not lost in the cosmos, but is lost with the cosmos,.

Fifth, patriarchal view (eco-feminism perspective). Rosemary Radford Ruether was among the pioneers of eco-feminism in early 1975, promoting the idea of a connection between the domination of women and the oppression and exploitation of nature. This concept emerges from conceding White's criticism of Judeo-Christian theology that it misrepresents Biblical texts as exploitative. In Ruether's view, such interpretation is greatly influenced by the dualistic context of universe and man, and by classical Greek philosophy regarding the segregation of soul and body as superior and inferior. The body or matter is inferior to the soul and is deemed the root of moral evil, a dogma that influences and shapes social hierarchy. In this regard, the superiority of the soul over the body aligns with the supremacy of male over female, master over slave, Greeks over barbarians and so on, to the extent that the dominance of a society over another is accepted as a norm. Through her eco-feminist movement, Ruether calls for change in the hierarchy of men and women, man and universe toward equality, as they rely on bio feedback [23]. Brian Swimme may also classify as an eco-feminist. His ideas come from the reality that science grows by for saking myth without the fear and awe that underpin deference to nature. Conversely, scientific reasoning is mechanistic and reductionist, firmly dictated by masculine norms and experiences. For example, the event delineating the universe's origins is more commonly named the "Big Bang,"Swimme contends that this demonstrates the masculine bias in science, and thus proposes poetic terms for scientific nomenclature to show greater feelings or nuances of admiration for the universe, respect for life, and a human life harmonious with all natural existence [24].

The last is the association of man and all creatures. Barbour [25] states that several scientific theories or discoveries, such as the study of ecosystem and ecology, have considerably proven the presence of complex interdependence and interconnection among life forms in this world. Knowledge can also raise awareness that man truly cannot be cut off from his reliance on and connection with others in the world. Furthermore, evolutionary biological theories indicate an association between man and every creature, and thus should bring about a new appreciation in man to pay greater respect to other creatures with the same history of cosmic origins. Nevertheless, such theories and discoveries will keep being contested by creationist practitioners and religionists. Basing their opinions on their comprehension of Scriptures, creationists fervently oppose the theory of evolution and believe that man does not share origins with other species.

\section{The Quranic Perspective}

For Muslims, the Quran is the most perfect Holy Scripture and Islam is the most comprehensive (kaffah) and most perfect religion as well. This understanding and belief rise from the Quran itself via the fifth ayah of surah al-Maidah which declares Islam as the sole perfect and blessed religion, and when Allah Instructs those who believe to enter al-Silmi (Islam, peace) totally (kaffah) (the Quran 2:208). However, though believed to be the most complete, this Book is then partialized by interpretations of its followers. Partial reading of verses about the environment lures the reader back to the snare of Western philosophy-based theories and tales distorted along history, to such an extent that latest interpretations of Quran verses seem to buttress those theories and accounts. 
All creatures are outspread verses of Allah that await for man's reading, as pointed out by 'Ali Imrân :190, "Indeed, in the creation of the heavens and the earth and the alternation of the night and the day are signs for ulul-albab." On this verse, al-Alûsî [26] criticizes mutaqaddimin scholars who tend to commentate that the alternation of night and day is predetermined by Allah and hence cannot be explored further by logic, whereas the author sees otherwise. For al-Alûsî, the alternation of night and day adheres to Sunnatullah in His Power and Will, which is following the movements of the heavens and earth. This is how the role of logic is taken into account [27].

\section{a. Man as Khalifah}

The word "khalifah" is found in the Quran, "And [mention, O Muhammad], when your Lord said to the angels, 'Indeed, I will make upon the earth a successive authority.' They said, 'Will You place upon it one who causes corruption therein and sheds blood, while we declare Your praise and sanctify You?' Allah said, 'Indeed, I know that which you do not know.'” (the Quran 2:30). According to Shihab [28], the term khalifah in this verse bears two meanings: First, Adam replaces jinn to inhabit the world, since jinn was dismissed as the previous dweller of Earth; second, Adam rules the earth on behalf of Allah in enforcing His laws thereon. Khalifah in this respect means al-niyabah or deputy [29]. Man as khalifah is the representative, successor, and ambassador of God on Earth. With his position as Allah's khalifah on Earth, man will be held responsible before Him [30]. The concession to prosper and manage the earth and its contents is bestowed upon man as a logical consequence of his willingness to hold Allah's trust [31] .Nonetheless, such comprehension also gives the impression of legitimizing man as subject over nature, despite differing from anthropocentrism, dualism, the intrinsic value of nature, eschatological orientation, patriarchal perspectives, and the association of man and all creatures. The distinction from the latter theory lies in the tenet that man is bound to his responsibility to God even though he still acts as subject. This insight is informed by tahlili and ijmali methods.

\section{b. Man as Bearer of God's Trust}

The Quran narrates the process of handing Trust to man, highlighting the oft penchant of trust bearers toward unfairness (the Quran/33:72). This verse explicates that man is the khalifah of Allah on Earth who has accepted His Trust, but is unjust and oblivious for betraying it. Trust is something that has to be fulfilled, "Indeed, Allah commands you to render trusts to whom they are due"(the Quran/4:58). The Arabic word for trust, al-amanah is derived from "أمن" which signifies custody of what is entrusted. In the Great Indonesian Dictionary [32], amanah is delineated as something entrusted to someone. It can also stand for peace, safety, security and harmony [33], or translate into true trustworthiness [34]. These denote that man as the one given trust must be able to bear it wholeheartedly in line with what has been entrusted to him, so that the trust-giver confides in him without reservations. Meanwhile, according to Muhammad [35], trust requires one to safeguard the entrusted item and return it to its owner unscathed. A trustworthy servant with full responsibility and discipline is the most special servant who is capable of understanding Allah's guidance and everything that he has to do in consequence. Amanah before Allah obligates a Muslim to observe all his duties and distance himself from all of His prohibitions [36]. 
To apply such ihsan (beautiful deeds), iman (faith) is a backbone, Islam is a form of fidelity and attribute to implement ihsan depictingan act which involves four aspects such as ihsan to God, personal, human beings, and other creators or nature [37]. Amanah in terms of environmental conservation as defined by Muhammad [38] is to maintain what is entrusted by the Trust-Giver (Allah) and return it to its Owner (Allah) intact. Nature is an amanah for man to preserve and harness from in accordance with the aims of its creation. This is substantiated by the avowal of hypocrites as reformers (al-muslihun) (al-Baqarah/2: 11-12). It is thereby fitting that the earth is entrusted to pious people with the potential of becoming actors of betterment. Allah Explicates that they are people who do harm but claim as those who reform (the Quran/2:11-12). The earth is delegated by Allah to man to be managed and handed back to its Owner (Allah) as a whole.

\section{c. Man as the noblest creature}

Nature, in this case, refers to earth and sky with all things provided by God for the benefit of mankind. Allah Rabb al'naturein maintains the natural environment and the world with compassion through the law of nature that he sets. Man has the opportunity to utilize this nature, processing or making use it as optimal as possible with all its facilities and capabilities, as the word of Allah in Hud /11: 61; "He has created you from the earth (sand) and provided you the prosperity" (Ministry of Religious Affairs of the Republic of Indonesia, 2012). Man was ordered to utilize and take the best benefit from the nature which is not absolutely justified to abandon the nature or destroy it. The ecological message in this verse lies in the sentence فيها واستعمركم) and which it makes you the prosperous). Literally, the word 'ista 'mara' is taken from the word 'amara' which means eternity, a long time [39] to lengthen age, prosper, build, and take care of things well [40]. While adding alif, sinn, tầ letters to amara, it is understood with various meanings. The inserts are meaningful demands. The term ista'mara means thalab al-ta'mî which demands two things, namely to maintain it in good condition, or to create a better condition [41].

When a man seeks to create a better situation, his action is both justified (salih)and is regarded as an actor of improvement (muslih). Muslih is the opposition of destructive nature (al-Mufsid). Muslih is the nature of believers who hold amanahtightly, while al-mufsid is a perpetrator of destruction like a hypocrite, but he claims to be a repair actor (al-Baqarah/2: 11-12). This view is different from the creationist perspective, which is worrying that man is trapped into an exploitative attitude as they see themselves as a being of noble character and has the highest position compared to other creatures. Glory man is not a patent, because according to the instructions of the Quran, its glory depends on how useful the life is.

\section{d. Earth is inherited to pious people}

With respect to current issues, it is concluded that the environmental issues have been a major concern. As a religion that emphasizes morals and ethics, Islam contributes to responding to the global discourse. For example, Mustafa Abu Sway stated that protecting and caring for the environment with piety is an obligation for every Muslim, and even becomes the main goal for the establishment of the Shari'a [42]. The principle of piety in managing the environment is interesting to note and study the message of the Quran regarding the inheritance of the earth which is only intended for pious people. This is in line with al-Anbiya (21: 105). 
Literally, the word al-ard is understood by some mufasir as the earth of heaven '(ard aljannah). That means, God's promise of inheritance and the victory of believers is the promise of life in the hereafter [43]. However, among the mufasir, some interpret the meaning of planet Earth, meaning that the promises apply in the world, not in the hereafter. If this is understood, the verse above contains the promise of mastery of the earth and its utilization rights only for the servants of God [44]. While the virtuous meaning in the above verse literally means good, true, valid, precise, competent, capable, virtuous, useful [45]. Thus, only people who are able to do good, virtuous, have competence, and are able to live peacefully with nature, which has the right to live and manage this earth.

All efforts to manage the environment with piety have been recorded by the Prophet Muhammad, such as the orientation to maintain animals with piety as directed by al-An'am / 6: 38 . Also, managing the earth with piety by planting it or not allowing it to be unemployed. In Islamic law, this activity is known as the ihyâ " al-mawât which means to flourish unproductive earth [46]. The concept of ihyām-mawât is Islamic shari'a in managing and utilizing the earth for the benefit of men both individually and collectively [47]. This enthusiasm is reflected in efforts to give value to an area which has no any benefits at all (unproductive land) into productive land, because it is made into fields, planted with fruits, vegetables and other crops [48].

Ecological piety is one of the implementation of the meaning of the Caliph. Ecological piety transforms man from salih to muslih. Saleh is managing the integrity of the environment. While muslih is an attitude to improve the environment which is damaged and needs some improvement to function as it is in line with the purpose of its creation as a means of serving and becoming a field of adventure of spirituality. This is in line with the instructions of surah al-Baqarah verse 11

and al-Anbiya 'verse 105. In other words nature has a material function as an instrument of spiritual adventure.

\section{e. Interpreting the vague verses}

To get into understanding of the highest level of spirituality, it is irrelevant to only read the verses of Quran, but man must read the verses of kawniyyah, namely the phenomenon of social context [49]. This is called vague verses. The mistake which occurs currently is the view that the clerics are good at reading the vague verses. Those who understand geology or other science experts are called scholars, though it is a socio-cultural construction. The real cleric is according to Quran instructions that experts' ability to read embodied in al-Baqarah / 2: 164 and al-A'raf / 7: 185.

Religion and science relations according to Ian G. Barbour can be classified into four features, namely, conflict, independence, dialogue, and integration. Dialogue and integration when applied in religious aspect, especially Islam which goes through the perspective of Islamic clerics, are important with the practice of religious education generally implement the conflict and independence paradigm, creating great influence on the formation of a culture of religious social thinking both in the private sphere and in the public sphere. The argument to be put forward is that the relationship between religions, in this casereligious sciences and integrative-interconnected modes of relationship [50]. Dialogue involve scientific paradigm should lead to the similar goal, that is an awareness of useful life. 


\section{f. Nature as a bridge (God's side)}

Second, tafakkur. Nature is the place for human beings toward Khalik (God). Spiritual exploration of men creates nature as the bridge of their hearts to reach the God's side. When they reach the highest level of sprituality, which is known in God's side, they will be said washil and reach the level of 'arif billah (recognizing God's features). Connecting with Ibn 'Atha'illah, he said, "Contemplation is the journey of soul through other than God. [51]. Contemplation in a Sufi perspective is an adventure of the heart to reach God's creation. Nature is a medium to reach God which requires human beings to preserve natur [52].Contemplation is the lamp of the heart. When it goes away, there is no light for it [53]. Tafakkur is the light to Allah, while nature is the axis of the heart's journey to Him. If the nature being damaged, then it will mislead the journey of life to get God's side. This is in line with Q.s. Ali 'Imran / 3: 190, that the phenomenon of the creation of the heaven and the earth, day and night change with which the verses show (signal and proof) Allah's power for ululalbab. The plenary man brings the treatise in the form of universal grace "rahmatan lil in naturein" as a statement of verse qawliyah "We did not send you (Muhammad as an Apostle) except to be a mercy to the universe" (Q.s. al-Anbiya ': 107).

\section{Conclusion}

Man and nature are two dimensions which are absolutely interconnected. Both cannot be separated because man needs nature, so does the nature. Between the verses contained (qawliyah) and the verses lieing both of them explain each other. Man is required to read the two verses to obtain complete instructions from Allah. Verses of qawliyah often become the concentration of ulama (clerics), while ayat kawniyah becomes an exploration by scientists. Both of them contain dichotomy interpetation. This is due to an academic socio-cultural construction, whereas in fact both of them complement each other to explain the relation between man and nature. Grounded in this fact, it needs such a discussion involving experts on verses of qawliyah and experts of kawniyah which is integrated and connected to obtain real instructions as a guideline in maximizing human beings' responsibilities as caliph on planet earth. By implementing the method of thematic interpretation, clerics and scientists should be an inseparable unit as the gap might result an extended dichotomy explaining the signals of divine greatness. On the other hand, clerics and scientists produce integrated science, and it is called in the Qur'an ulul albab, which integrtes dzikir and pikir (spirituality and intelligence). The results of their reading or researchs should be used as a guide for ulul amri (leaders) in carrying out the tasks of the Caliphate structurally. In other words, the research-based policy of Ulul Albab was applied in the Ulul Amri policy.

\section{References}

[1] Hilda, L. "Islam and Lingkungan Hidup". Hikmah, 7(2). Retrieved from http://jurnal.iainpadangsidimpuan.ac.id/index.php/Hik/article/view/62, 2013.

[2] Abduh, M. R. and W. A. G. Spritualitas Lingkungan and Ekonomi Industri. Yogyakarta: CRSD Yogyakarta. https://doi.org/10.14421/jpi.2015.42.373-389, 2007.

[3] Yusuf, M. Epistemologi Islam: Landasan Mengatasi KrisisIptek Modern and Dampak Globalisasi in Perspektif Al-Qur'an. Sorong, Papua Barat Indonesia: Pustaka Rafana STAIN Sorong, 2011. 
[4] Abduh, M. R. and W. A. G. Spritualitas Lingkungan and Ekonomi Industri. Yogyakarta: CRSD Yogyakarta. https://doi.org/10.14421/jpi.2015.42. pp. 373-389, 2007.

[5] Mutia, M. (2018). Teknologi in Alquran. Jurnal Ilmiah Islam Futura, 6(2), pp. 70-77 https://doi.org/10.22373/JIIF.V6I2.3048, 2018.

[6] Meraj, M. A. Islamic Approach to The Environment to the Enronment and rhe Ro Protected. Jurnal Ilmiah Peuradeun, 4 (1), pp. 1-4, 2016.

[7] Beck, J., \& Welker, M. Filtered Containment Venting: Reasons, Technology, Impact on Environment. Journal of Energy and Power Engineering, 10, pp. 765-769 https://doi.org/10.17265/1934-8975/2016.12.007, 2016.

[8] Beck, J., \& Welker, M. Filtered Containment Venting: Reasons, Technology, Impact on Environment. Journal of Energy and Power Engineering, 10, pp. 765-769 https://doi.org/10.17265/1934-8975/2016.12.007, 2016.

[9] 'Abd al-Baqiy, F. al-Mu'jum al-Mufahras li Alfaz al-Qur'an al-Karim. Beirut-Libanon: Dar al-Ma'rifa, 2012.

[10] Zarqani, Muhammad Abd al-'Azhim al-. Manhij al-'Irfan fi 'Ulum al-Qur'an. Jilid 1 Cet. I; al-Qhirah: al-Halabi, 1988.

[11] Zarkasyi, Badr al-Din. Al-Burhan fi 'Ulum al-Qur'an. Jilid 1, Cet. I; al-Qahirah: alHalabi(n.d).

[12] Yusuf, Muhammad. Horizon Kajian Alquran: Pendekatan and Metode. Edited by AanFarhani. 1st ed. Makassar, Indoensia: Alauddin Press, 2014.

[13] Al-Zarqani, Muhammad Abd al-'Azhim. Manhij al-'Irfan fi 'Ulum al-Qur'an. Jilid 2. Cet. I; al-Qhirah: al-Halabi, 1988.

[14] Timm, R. E. "Dampak Ekologis Teologi Penciptaan menurut Islam," in Agama, Filsafat, \& Lingkungan Hidup, p.109 (n.d).

[15] White, L. J.. "The Historical Roots of Our Ecological Crisis [with discussion of St Francis; reprint, 1967]" Ecology and religion in history. New York: Harper and Row, 1974.

[16] White, L. J. (1974). "The Historical Roots of Our Ecological Crisis [with discussion of St Francis; reprint, 1967]" Ecology and religion in history. New York: Harper and Row, 1974.

[17] Özdemir, I. (n.d.). "Toward an Understanding of Environmental Ethics from a Qur'anic Perspective." In Islaam and Ecology, p. 5 (n.d).

[18] Timm, R. E. "Dampak Ekologis Teologi Penciptaan menurut Islam," in Agama, Filsafat, \& Lingkungan Hidup, p. 110 (n.d).

[19] Özdemir, I. "Toward an Understanding of Environmental Ethics from a Qur'anic Perspective." In Islam and Ecologyp. 5 (n.d).

[20] Timm, R. E. (n.d.). "Dampak Ekologis Teologi Penciptaan menurut Islam," in Agama, Filsafat, \& Lingkungan Hidup, p.112 (n.d.).

[21] Haught, J. Perjumpaan Sains and Agama: Dari Konflikke Dialog, terj. Fransiskus Borgias. Bandung: Penerbit Mizan, 2004.

[22] Haught, J. "Ecology: Restoring Our Sense of Belonging" Woodstock Report 38, Juni1994,. Retrieved from http://www.georgetown.edu/centers/woodstock/ report/rfea38.htm, 2006.

[23] Peeters, D. , "Toward an Ecologically Informed Theology,." In Theology Digest, 40 Number., p.115 , 1993.

[24] Peeters, D. "Toward an Ecologically Informed Theology,.” In Theology Digest, 40 Number., 
p.117, 1993.

[25] Barbour, I.. Menemukan Tuhan in Sains Kontemporer and Agama, terj. Fransiskus Borgias,. Bandung: Penerbit Mizan, 2005.

[26] al-Alûsî, A. al-F. S. al-D. al-S. M. Rûh al-Ma’ânî, Juz IV. BairutLubnan: Dar al-Fikr, 1983.

[27] Setianingsih, Y. Melacak pemikiran al-alûsî in tafsirrûh al-ma’ânî. Kontemplasi, 05 No. 01, 2017.

[28] Shihab, U. Kontekstualitas Al-Qur,an; Kajian Tematik Ayat-ayat Hukum in Al-Qurean, Jakarta, Indonesia: Paramadina, 2005.

[29] al-Ashfahani, al-R. Al-Mufradat fi GharibAlqur'an. Ar-Raghib al-Ashfahani, Al-Mufradat fi GharibAlqurean (Tanpa Kota: Maktabah Nazar Musthofa al-Baz: Maktabah Nazar Musthofa al-Baz (n.d).

[30] Ilyas, R. Man Sebagai Khalifah. Mawa`izh, 1(7), pp. 169-195, 2016.

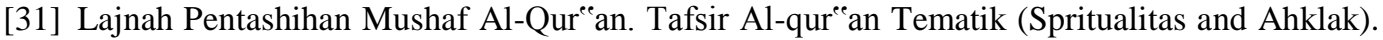
Jakarta: Aku Bisa, 2012.

[32] Tim Prima Pena. Kamus Besar Bahasa Indonesia (terbaru). Jakarta Indonesia: Gitamedia Press (n.d.).

[33] Mohamad, A. \& Z. M. Konsep Amanah In Pengurusan Islam Dari Sudut Maqasid Syariah (Penjagaan Harta). Proseding Seminar antar bangsa pengurusan and kepemimpinan Islam. In Proseding Seminar antar bangsa pengurusan and kepemimpinan Islam. Malaysia (n.d).

[34] Darimis. REM-BEKAS (Revolusi Mental Berbasis Konseling Spritual Teistik): Upaya Membangun Generasi Berkarakter FAST (Fathonah, Amanah, Siddiq, and Tabligh). JurnalTa'dib, 18 No. 1, 2015.

[35] Muhammad, H. Wasiat Taqwaulama'-ulama' al azhar-Kairo. Jakarta: Bulan Bintang, 1986.

[36] Supriono, A. Seratus Cerita Tentang Akhlak. Jakarta: Republika, 2004.

[37] Zainudin \& Muhammad Jamhari. Al Islam 1: aqidah and ibadah. Bandung: CV. PustakaSetia, 1999.

[38] Muhammad, H. Wasiat Taqwaulama'-ulama' al azhar-Kairo. Jakarta: Bulan Bintang, 1986.

[39] Ibnu Faris, A. al-H. A. Mueejam M aqayis Al-Lughah. Beirut, Libanon: Dar al-Fikr, 1994.

[40] Ibrahim, M. I. Mu "jam Alfazh Al-Qur"ean, 2 (Kairo: Dar Al-Fikr al-'Arabi, 1969, p. 632.

[41] Al-Sya'rawi, M. M. (n.d.). 39 Muhammad Mutawalli al-Sya'rawi, -Tafsir Al-Sya'rawi,\| in CD-Room Maktabah Syamilah, 11,p. 6528..

[42] Sway, M. A. Towards an Islamic Jurisprudence of the Environment. Retrieved from https://www.missionislam.com/science/enviroment.html, 2016.

[43] Shihab, M. Q. Tafsir Al-Misbah, VIII. Jakarta: LenteraHati, 2002.

[44] Al-Asfahani, al-R. Al-Mufradat Fi Gharib Al-Qureean. Kairo: al-Maktabahal Tawfiqiyyah, 2003.

[45] Baalbaki, R. Al-Maurid a Modern Arabic-English Dictionary (Beirut: Dar al-'Ilm li al Malayin, 1995.

[46] Mangunjaya, F. Syariah: Jalan Keluar Dari Krisis Ekologi. Jurnal Ulumul Qur'an 7, No. 1, 7 No. 1, p.91, 1998.

[47] Nafisah, M. Alquran and Konservasi Lingkungan (Suatu Pendekatan Maqâsid al-Syarî'ah). AL QUDS: Jurnal Studi Al Quran and Hadis, 2, No. 1, 1-28. https://doi.org/: http://dx.doi.org/10.29240/alquds.v2i1.405, 2018.

[48] Masruri, U. N. Pelestarian Lingkungan In Perpektif Sunnah. At-Taqaddum, 6, No. $2,421$. 
https://doi.org/10.21580/at.v6i2.718, 2016.

[49] Hasyim, M. S. al-'Nature in Alquran, Analisis tentang Ayat-ayat Penciptaan. Hunafa: Jurnal Studi Islamica, 9 No. 1, 55-84, 2012.

[50] Khoiruddin, A. Sains Islam Berbasis Nalar Ayat-ayat Semesta. Jurnal At-Ta'dib, 7 No. 2. Retrieved from https://www.researchgate.net/publication/319014694_Sains_Islam_Berbasis_Nalar_Ayatayat_Semesta, 2017.

[51] As-Sakandari, Ibn 'Atha'illah. (n.d.). Al-Hikam. Mesir.

[52] As-Sakandari, Ibn 'Atha'illah. (n.d.). Al-Hikam. Mesir.

[53] Firdaus, I. (2016). al-Hikam ibn Atha'illah As-Sakandari Edisi Lengkap 3 Bahasa. (Y. dkk. Indrayadi, Ed.) (Lengkap 3). Jakarta Selatan: Wali Pustaka. 